\title{
Preferált vezetési stílus, vezetői és vállalkozói hajlandóság az egyetemi hallgatók körében ${ }^{1}$
}

\author{
GYŐRI ÁGNES² - LENGYEL GYÖRGY3 - PERPÉK ÉVA ${ }^{4}$
}

\begin{abstract}
ABSZTRAKT
Jóllehet számos kutatás született vezetôi stílusok témakörben, és az egyetemi hallgatók kezdetektôl gyakori szereplói a feltáró jellegü társadalomtudományi kutatásoknak, kevesebb példát találunk arra, hogy a Full Range Leadership modellt fiatalok körében alkalmazzák. Ebben a cikkben a szerzők magyar egyetemisták körében vizsgálják a preferált vezetői stílusokat, és ezeket a vezetői és vállalkozói aspirációkkal összefüggésben térképezik fel. A kutatásban felhasznált online kérdőivet fövárosi és vidéki egyetemek gazdasági, müszaki és társadalomtudományi képzéseiben tanuló diákok töltötték ki. A kérdőív kitöltésében 335 egyetemi hallgató múködött közre. Az eredmények feltáró jellegüek és a szakirodalom alapján várható összefüggéseket néhány ponton módosítják. Négy jól elhatárolható vezetési stílus rajzolódott ki a vizsgált egyetemisták körében, melyek a transzformatív, a szupportív, a defenzív és a laissez-faire vezetöi típusokat testesítik meg. Többváltozós elemzés alapján azt a feltevést fogalmazhatjuk meg, hogy az egyetemi hallgatók körében a vezetöi hajlandóság a transzformatív vezetési stílusjegyekkel, míg a vállalkozói aspirációk a transzformatív és a szupportív vezetói stílussal mutatnak pozitív összefüggést.
\end{abstract}

KULCSSZAVAK: vezetési stílus, vezetői aspirációk, vállalkozói hajlandóság, egyetemisták

\section{ABSTRACT \\ Preferred leadership style, leadership and entrepreneurial inclination among university students}

Although many researches have been conducted on leadership styles and university students are participants in exploratory social science research quite frequently, fewer examples can be found on the application of the Full Range Leadership model among the youth. In this article, the authors examine preferred leadership styles among Hungarian students, and map their connections with managerial and entrepreneurial inclination. The online questionnaire used in

\footnotetext{
${ }^{1}$ A tanulmány a Széchenyi 2020 program EFOP-3.6.1-16-2016-00013 „Intelligens szakosodást szolgáló intézményi fejlesztések a Budapesti Corvinus Egyetem székesfehérvári Campusán” című európai uniós projektje keretében készült. A kutatás támogatását ezúton köszönjük. Köszönetünket fejezzük ki továbbá a névtelen lektornak kritikai észrevételeiért.

2 Társadalomtudományi Kutatóközpont, gyori.agnes@tk.mta.hu.

${ }^{3}$ Budapesti Corvinus Egyetem, gyorgy.lengyel@uni-corvinus.hu.

${ }^{4}$ Társadalomtudományi Kutatóközpont, perpek.eva@tk.mta.hu.
} 


\section{TEMATIKUS TANULMÁNYOK - Emberierőforrás-menedzsment napjainkban}

the research was completed by university students studying economics, technology and social studies in the capital and beyond. The questionnaire was completed by 335 university students. The results are exploratory, and they seem to modify the existing typologies. Four distinct leadership styles could be observed within the target group, embodying the transformative, supportive, defensive, and laissez-faire leadership types. Based on multivariate analysis one may suppose that among students leadership willingness is positively connected to transformative leadership, while entrepreneurial inclination to the transformative and supportive styles.

KEYWORDS: preferred leadership style, leadership aspirations, entrepreneurial inclination, university students

\section{Bevezetés}

Írásunkban azt vizsgáljuk, hogy milyen vezetési stílussal azonosulnak a felsőoktatási hallgatók, milyen tényezőkkel állnak összefüggésben vezetői aspirációik és vállalkozói hajlandóságuk. A vezetői stílusokat a Full Range Leadership modell szellemében tanulmányozzuk. Annak ellenére, hogy számos kutatás született vezetői stílusok témakörben (Gregor - O’Brien 2015, Sin Ping 2001, Sheppard 2018) és a Full Range Leadership modell alkalmazása is viszonylag széles körben elterjedt a nemzetközi menedzsment kutatásokban, kevés példát találni arra, hogy azt majdani vezetők és munkaerőpiaci résztvevők több száz fős mintáján teszteljék.

A fiatalok és a felnőtt népesség vállalkozói hajlandóságának, valamint maguknak a vállalkozásoknak a kutatása ennél kiaknázottabb terület (Kuczi et al. 1991, Lengyel - Róna-Tas 1997, Kuczi - Lengyel 2001, Fitzsimmons et al. 2005, Lengyel 2008, Lengyel 2009). Ami a kurrens nemzetközi összehasonlító kutatásokat illeti, Magyarország 2006 óta részese a Global University Entrepreneurial Spirit Students' Survey - GUESSS nemzetközi felmérésnek, amelynek egyes vizsgálati szempontjait mi is beépítettük a vizsgálatunkba. Kutatásunk hozzáadott értékét az adja, hogy fiatalok körében vizsgáljuk a preferált vezetői stílusokat, s ezeket a vezetői és vállalkozói hajlandósággal összefüggésben térképezzük fel.

Írásunkban egy magyar egyetemisták körében 2018-ban készült online survey eredményeit mutatjuk be. Vizsgálatunk összehasonlító jellegü: különböző képzésekben résztvevő egyetemi hallgatók, fővárosi és vidéki diákok almintáját vetjük össze.

A cikkben először bemutatjuk a leadership irodalom alapján a vezetői stílusok elméleti modelljeit, majd a vezetői és vállalkozói hajlandóság nemzetközi, illetve hazai vizsgálatainak - elemzésünk szempontjából fontos - eredményeiről nyújtunk áttekintést. Ezután ismertetjük a felhasznált adatbázist, az elemzés változóit és az alkalmazott módszereket. Az eredményekre térve feltárjuk, hogy milyen vezetői típusokat preferálnak az egyetemisták, és megvizsgáljuk, hogy az egyes típusokkal való azonosulás a válaszadók mely csoportjaira jellemző, majd bemutatjuk a vezetési stílusokra kidolgozott regressziós modelleket. Végül röviden összefoglaljuk következtetéseinket. 


\section{TEMATIKUS TANULMÁNYOK - Emberierőforrás-menedzsment napjainkban}

\section{Elméleti felvetések és empirikus kutatási előzmények}

A leadership irodalom egyik meghatározó alakjaként Kurt Lewin az 1930-as évek végén a gyakorlatban is jól hasznosítható elméletet dolgozott ki, kísérleti módszerrel alátámasztva. ${ }^{5}$ A kísérletben résztvevők a demokratikus vezetésű csoportban kisebb ellenségességet és agressziót mutattak, mint az autokratikusban. A kísérletek körülményeit, valamint a vezetés demokratikus és autokratikus jellegét azóta számos (ön)kritika érte. Mint ahogyan azt is, hogy a laissez-faire típusú vezetés alkalmazása eredetileg nem volt tervezett, azt Lewin a kísérlet megmentése és a demokrácia hírnevének védelme érdekében vezette be mintegy retorikai fogásként (Billig 2015).

A vezetéselmélet másik klasszikusa, Rensis Likert az autokratikus-demokratikus fogalompárhoz illeszkedve kétszer két vezetői stílust dolgozott ki: kizsákmányoló parancsoló, jóindulatú parancsoló, konzultatív és participatív stílusokat. A kizsákmányoló-parancsoló vezetés hierarchikus, a vezető szoros kontrollt gyakorol a vezetettek felett, és megfélemlítéssel sarkallja őket magas teljesítményre. A jóindulatú parancsoló vezető ezzel szemben paternalisztikus gondoskodással ötvözi a fentieket. A konzultatív vezetésben az információáramlás többirányú, kikérik a vezetettek véleményét, azonban a döntéseket a vezetők hozzák. A vezetettek alapvető motivációja a jutalmak megszerzése és a büntetésék elkerülése. A Likert által favorizált rendszer a participatív vezetés. Ebben a rendszerben a vezetettek részt vesznek mind a célok kijelölésében, mind a döntéshozásban, ezáltal felelősségvállalás és elszámoltathatóság jellemzi őket (Likert 1967).

A hatékony vezetés tranzaktív és transzformatív modellje szerint a (politikai) vezetés több az engedelmesség kikényszerítésénél (Burns 1978, Bryman 1996, Boda 2013). Weberi terminusokban gondolkodva a vezetés a legitim uralom tartományában értelmezhető. Tranzaktív vezetési stílus esetén a cél elérésének módja a vezetettek számára közvetlenül elérhető haszon (siker, elismerés, anyagi ellentételezés) és veszteség lehetőségének érzékeltetése. A transzformatív vezető általában ennél elvontabb eszközökkel (közös cél, küldetés, vízió) motivál, s a transzformatív vezetés morális jelleget is ölthet. Bár Burns leadership elméletét számos kritika érte, mégis termékenyítőleg hatott az empirikus kutatásokra.

A menedzsment irodalomban elfogadott, általunk alkalmazott Full Range Leadership modell (Bass 1985) is Burns szellemét követve alakult ki. A modellben a transzformatív és tranzaktív vezetői stílus mellé bevezetik a laissez-faire stílust. Az eredeti Full Range Leadership modellben a tranzaktív vezetői stílust a feltételes jutalmazás és a kivételeken/kifogásokon alapuló aktív vezetői faktorok képezik.

\footnotetext{
${ }^{5}$ Lewin tanítványaival először két, 11 évesekből - főként fiúkból - álló, maszkkészítésre szerveződött csoportban tesztelte az autokratikus és demokratikus vezető vezetettekre gyakorolt hatását. Később a kísérletben résztvevő csoportok száma négyre emelkedett, a vezetői szerep pedig a laissez-faire típussal bővült.
} 


\section{TEMATIKUS TANULMÁNYOK - Emberierőforrás-menedzsment napjainkban}

A feltételes jutalmazás (rewards achievement/contingent reward) során világosak a feladatok, a célok, valamint a teljesítmény alacsony, közepes és magas szintjéhez rendelt jutalmak és büntetések. A transzformatív vezetés azt takarja, hogy a vezető az átalakulás perspektíváját kínálja és átalakítja a vezetetteket, hiszen azokat az általuk eredetileg szándékoltnál nagyobb és jobb teljesítményre sarkallja (Stafford 2010). Fontos hangsúlyoznunk, hogy a tranzaktív és transzformatív nem feltétlenül egymást kizáró, hanem párhuzamosan alkalmazott, egymást kiegészítő vezetői típusok (Avolio - Bass - Jung 1999); helyzete válogatja, hogy melyik fajta vezetői viselkedés a leghatékonyabb. Edwards és Gill (2012) kimutatta, hogy míg a transzformatív vezetői stílus a hierarchia összes szintjén hatékony, addig a tranzaktív típus inkább csak az alsó szinteken. A laissez-faire vezetési típus egyetlen vezetési szinten sem bizonyult hatékonynak. A nemzetközi kutatási eredmények értelmében azon szervezeti egységek működnek hatékonyabban, amelyek vezetői a transzformatív típusba tartoznak (Lowe - Kroeck - Sivasubramaniam 1996). Ehhez képest Zaal (2017, N = 6 vezető, 36 alkalmazott) disszertációjában azt találta, hogy mind a tranzaktív, mind a transzformatív vezetői stílus nagyobb csapatsikert produkált, mint az autokratikus. Ami a nemeket illeti, eredményei szerint a nők inkább a transzformatív, a férfiak inkább a tranzaktív típusú vezetést kultiválják.

A Full Range Leadership modell konceptualizálására és operacionalizálására egyik leggyakrabban használt és legmegbízhatóbb mérőeszköz a Multifactor Leadership Questionnaire (Avolio - Bass 1990, Avolio - Bass - Jung 1996). A kérdőív egyik előnye, hogy lehetőséget ad több szemszögből megvizsgálni a vezetési stílusokat. A vezető nyilatkozhat ugyanis saját vezetői stílusáról, teret adva az önreflexiónak egyfelől, a vezetettek pedig ugyanezen szempontok szerint véleményt nyilváníthatnak főnökük vezetési stílusáról, megteremtve a visszajelzés lehetőségét másfelől. A kérdőívnek létezik továbbá csapatokra kiterjesztett, valamint az aktuális és kívánatos helyzetet felmérő változata is. Kutatásunkban a Multifactor Leadership Questionnaire (MLQ) öt változata közül az önértékelő verzió szűkített, 36 itemes skáláját használtuk. A kérdőív széles körben használatos menedzsmentkutatásokban, ám az oktatásban, egészségügyben vagy közigazgatásban dolgozók körében is egyre gyakrabban alkalmazzák világszerte. Egyesek az MLQ korlátai között említik, hogy a vezetői stílusok korrelálnak egymással, és ez rontja a mérőeszköz érvényességét. Mások szerint az MLQ túlhangsúlyozza a vezetői szerepet, elhanyagolva olyan releváns tényezőket, mint a szervezeti jellegzetességek, személyközi kapcsolatok vagy a vezetői hierarchiában elfoglalt hely (Kelloway - Barling - Helleur 2000, Edwards Gill 2012). Továbbá, meg kell jegyeznünk, hogy a kérdőív percepciókon alapszik, ilyen értelemben nem tekinthető a vezetés hatékonyságát objektíven mérő eszköznek. Mindezekkel a korlátokkal együtt az MLQ-t kipróbálásra alkalmasnak találtuk magyar hallgatói mintán.

A Multifactor Leadership Questionnaire-t kis elemszámú magyar mintán Filep (2018) tesztelte. Vizsgálatában 23 Szabolcs-Szatmár-Bereg megyei kisvállalkozás 


\section{TEMATIKUS TANULMÁNYOK - Emberierőforrás-menedzsment napjainkban}

vezetőjével töltette ki az MLQ kívánatos és aktuális vezetői stílust összehasonlító változatát. Eredményei szerint a vezetők leginkább a tranzaktív és transzformatív vezetői típust megtestesítő feltételes jutalmazás és idealizált befolyásolás irányába szeretnének elmozdulni. Meglátása szerint a transzformatív vezetési stílust alkalmazó vállalkozások valamivel sikeresebbek a többieknél, amennyiben az árbevétel-arányos nyereség vonatkozásában hibahatáron belüli enyhe többletet tapasztalt.

Saját kutatási eredményeink - mint arról alább részletesebben szólunk - arra utalnak, hogy a Full Range Leadership modell négy típust rajzol ki a vizsgált mintán: a transzformatív, a szupportív, a defenzív és a laissez-faire vezetői stílus típusát. Az első, transzformatív vezetői típusnak három jellegzetes jegye van: a vízió, a bizalomépítés képessége és az integritás. A második típusba a szupportív vezetői jellemzők tartoznak, amelyek két csoportban, a személyre szabott mentorálás és a szellemi ösztönzés vonásaiban ragadhatók meg. Az adaptált Full Range Leadership modell harmadik elkülönülő vezetési stílusa a defenzív, ami hibákra koncentrálást és aktív korrekciót takar. Ebben az esetben tehát egy cselekvő, aktívan védekező vezető képe rajzolódik ki előttünk. A negyedik, laissez-faire stílus tulajdonképpen az aktív vezetés elutasítását, a be nem avatkozást, kivételeken alapuló irányítást és a tűzoltó jellegű problémamegoldást jelenti, anélkül hogy feltárnák az okokat és megelőznék azok újbóli kialakulását (Avolio - Bass 1996, Bass - Avolio 2004, Filep 2018, Stafford 2010).

Az 1. ábra az aktív-passzív, valamint a hatékony-nem hatékony dimenziókban értelmezi a négy adekvát vezetési stílust és az általunk módosított Full Range Leadership modellt.

1. ábra. Full Range Leadership modell: adaptáció

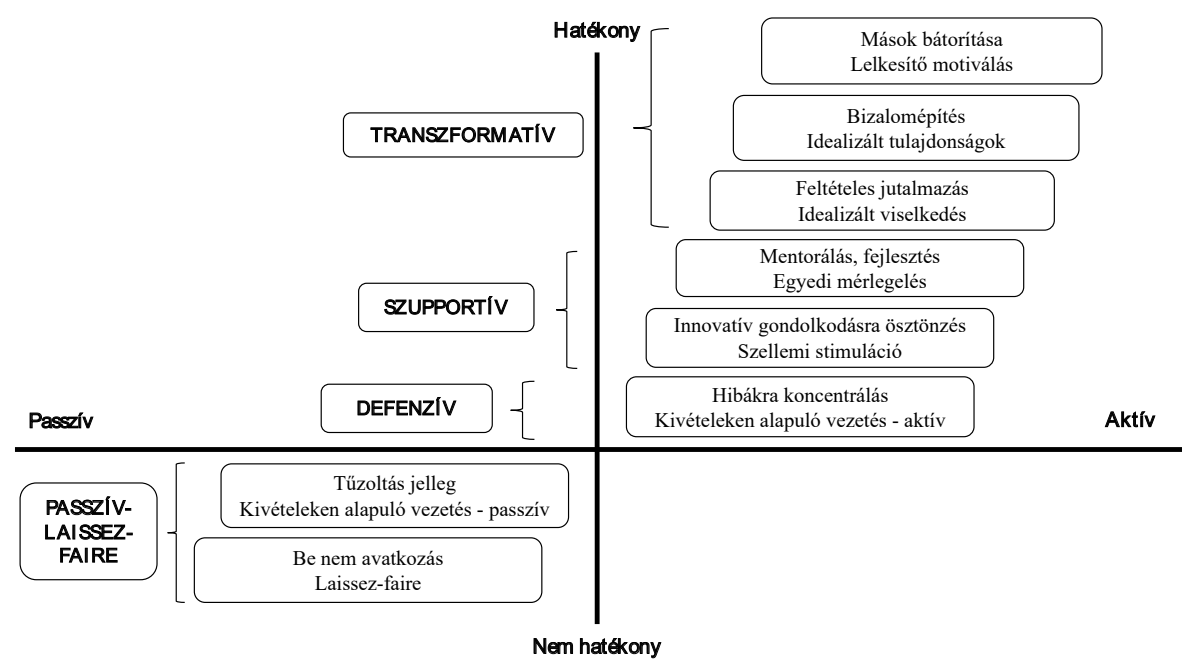

Forrás: Avolio - Bass (1996), Chancy (2017) alapján saját szerkesztés 


\section{TEMATIKUS TANULMÁNYOK - Emberierőforrás-menedzsment napjainkban}

Kutatásunk másik fókusza a vállalkozói potenciál vizsgálata. Krueger és Brazeal (1994), valamint Lengyel (2008) hangsúlyozza, hogy a vállalkozói hajlandóság elkülönítendő a konkrét vállalkozási szándéktól, annál tágabb, s egyfajta személyes nyitottságot jelent a vállalkozás elvi lehetősége iránt. Korábban Shapero és Sokol (1982) a ma számos tudományterületen kurrens „reziliens” és „önmegújító” jelzőt alkalmazza arra a gazdasági környezetre, amely kedvez a potenciális vállalkozóknak. A vállalkozói hajlandóságot középpontba állító számottevő vizsgálatok között említhetők Etzioni (1987), Radaev (1997), Fitzsimmons és Evans (2005), valamint Lengyel $(1996,2008)$ kutatásai.

Lengyel (2008) vizsgálatai az 1988-2007 közötti időszakot ölelik fel a vállalkozói hajlandóság tekintetében. Az eredmények értelmében a kilencvenes években a vállalkozói potenciál erősebb volt a férfiak és fiatalok körében. A társadalmi helyzet is pozitív összefüggést mutatott a vállalkozói hajlandósággal: nagyobb mértékben lettek volna vállalkozók azok, akik magukat a felső- vagy középosztályba sorolták, mint az alsó- vagy alsó-középosztály tagjai. Az iskolai végzettség szintén jelentősen befolyásolta a vállalkozási hajlandóságot: a gondolat legnépszerübb a szakmunkás és szakközépiskolai végzettségűek körében volt, míg a felsőfokú végzettségűek vállalkozói kedve csak némileg múlta felül az átlagot.

Egyes kutatások kimutatták, hogy a vállalkozói potenciál a vállalkozás sikerességének egyik záloga (Rauch et al. 2009, Hofmeister et al. 2015). A vezetői stílusok közül ez az attitűd- és viselkedéscsomag átfedést mutat a transzformatív vezetői stílussal, azzal kiegészítve, hogy a vezető saját ambícióit, valamint a szervezet érdekeit képes közvetíteni a vezetettek felé, így ösztönözve őket a szervezettel való azonosulásra és maximális teljesítményre. Ezt a gondolatmenetet követve és a nemzetközi kutatási eredményekhez igazodva tehát az feltételezhető, hogy a transzformatív vezetési stílus és a vállalkozói hajlandóság között szignifikáns pozitív kapcsolat van.

Hofmeister és szerzőtársai (2015) 2011-ben végeztek kutatást kétszázas elemszámú magyar mikro-, kis- és középvállalkozói mintán vállalkozói szellem és vezetői stílusok témakörben. Értelmezésükben a vezetők vállalkozói hajlandósága proaktivitást, kockázatvállalást, valamint a schumpeteri innovatív szemléletet és ambiciózus viselkedést takarja. A nemzetközi elméletekből kiindulva a vállalkozót, a vállalkozói szellemet megkülönböztetik a kisvállalati orientációtól, a kisvállalkozás tulajdonlásától. Hofmeister és szerzőtársai kimutatták, hogy a vállalkozói szellem egyes elemei összefüggenek a vezetési stílusokkal. Az eredményeket korlátozza, hogy a nemzetközi kutatási gyakorlatból adaptált vállalkozói szellem skála megbízhatósága alacsony volt. Pozitív kapcsolatot detektáltak az innováció és a demokratikus, valamint támogató vezetés, illetve a proaktivitás és a támogató vezetés között. Ezzel szemben negatív összefüggést mutattak ki a kockázatvállalás és a demokratikus, valamint a konzultatív vezetői típusok között. Ehhez képest Dzomonda és szerzőtársai (2017) ( $\mathrm{N}=103$ vezető) a vállalkozói szellem magyarázatára használták a vezetői típusokat. Kimutatták, hogy mind a tranzaktív, mind a transzformatív vezetési stílus összefügg 


\section{TEMATIKUS TANULMÁNYOK - Emberierőforrás-menedzsment napjainkban}

a vállalkozói orientációval, és a kapcsolat a transzformatív vezetési stílus esetében erősebb. Öncer (2013) ( $\mathrm{N}=171$ alkalmazott) azt mutatta ki, hogy míg a tranzaktív vezetési stílus csak egy vállalkozói orientáció dimenzióval áll pozitív összefüggésben, addig a transzformatív stílus lényegében mindhárommal.

A legkiterjedtebb nemzetközi kutatás, amely a fiatalok karrierválasztási terveit köztük a vállalkozási szándékot - vizsgálja, a Global University Entrepreneurial Spirit Students' Survey, más néven GUESSS. A kutatást a St. Galleni egyetem koordinálja. A 2016-os felmérés ötven országban több, mint ezer egyetemen több, mint 122 ezer hallgató részvételével zajlott. A kutatást először 2003-ban végezték, magyar felsőoktatási intézmények 2006-ban kapcsolódtak be a vizsgálatba. A magyar részvétellel zajló 2006-os, 2008-as, 2011-es, 2016-os felmérésekből számos elemzés született (Szerb - Lukovszki 2013, Petheő 2013, Koltai - Szalka 2013, Imreh-Tóth et al. 2013, Reisinger 2013, Temesi 2014, S. Gubik 2015, Farkas - S. Gubik 2016). A legfrissebb publikált GUESSS eredmények szerint a magyar hallgatók diplomaszerzés utáni vállalkozási kedve alacsonyabb, mint külföldi társaiké, az alkalmazotti létet preferálják az önállósodással szemben. Mindössze körülbelül minden huszadik, a felsőoktatásban tanuló magyar hallgató nyilatkozta azt, hogy a végzést követően önálló vállalkozást szeretne alapítani. Ez az arány elmarad mind az Európai Unió, mind a visegrádi országok átlagától. A magyar fiatalok távolabbi, munkatapasztalat-szerzés utáni terveiben ugyanakkor egyértelműen szerepel a vállalkozás és független munkavégzés gondolata: öt évvel a végzés utáni időszakra vonatkozóan a megkérdezettek kb. egyharmada válaszolta, hogy karrier aspirációi között szerepel az önálló vállalkozás alapítása (S. Gubik - Farkas 2017). A diákok karrier-aspirációit feltérképező vizsgálatok közül nemzetközi szinten például Gregor és O’Brien (2015), és Sheppard (2018) gender fókuszú kutatásai emelendők ki.

\section{Adatok és minta}

Az elemzés a Budapesti Corvinus Egyetem SocioLab kutatócsoportja ${ }^{6}$ által 2018-ban lebonyolított online kérdőíves felmérés adatbázisának feldolgozásán alapszik. Kutatásunk gazdasági, műszaki, természet- és társadalomtudományi területeken tanuló egyetemisták körében tárta fel, hogy milyen vezetési stílussal azonosulnak a fiatalok, és hogy az általuk preferált vezetői stílusjegyek milyen szociodemográfiai és egyéb sajátosságokkal bírnak. Vizsgálatunk fő célkitűzése a potenciális vezetői stílusok és a vállalkozói, vezetői aspirációk összefüggésének vizsgálata volt.

A minta kialakításakor a reprezentativitás nem volt célunk, ugyanakkor az igen, hogy a feltárt összefüggések nyomán a társadalmi sajátosságokra vonatkozóan hipotéziseket fogalmazhassunk meg. A felmérésre 2018 októbere és novembere

${ }^{6}$ A kutatócsoport tagja volt a jelen cikk szerzőin túl Bársony Fanni, Czakó Ágnes, Horváth Vera és Horzsa Gergely. 


\section{TEMATIKUS TANULMÁNYOK - Emberierőforrás-menedzsment napjainkban}

között került sor.7 A szűrőfeltételek alkalmazása és az adatbázis tisztítása után az empirikus elemzéshez felhasznált minta 335 diák adatait tartalmazza. ${ }^{8}$ Ez a mintaelemszám az általunk áttekintett vezetői stílusok vizsgálatának nagy részéhez (Zaal 2017, Hofmeister et al. 2015, Dzomonda et al. 2017, Öncer 2013, Filep 2018) képest kifejezetten magasnak minősül.

A mintába 18-24 év közötti válaszadók kerültek be, akiknek négyötöde (82\%-a) alapszakos (BA/BSc) hallgató. A nemek szerinti összetételt tekintve több lány válaszolt, mint fiú (60\%-uk lány, 40\%-uk fiú). A kitöltők majdnem fele (47,8\%) Közép-Magyarországon (Budapesten, Gödöllőn), harmada (36\%) a Közép-Dunántúlon (Dunaújvárosban, Székesfehérváron, Veszprémben) és közel hatoda (16,1\%) egyéb vidéki egyetemeken (Debrecenben, Nyíregyházán, Szegeden, Pécsett) tanul. A válaszadók mintegy fele $(48,6 \%)$ társadalomtudományi, harmada $(33,9 \%)$ műszaki, illetve természettudományi területen tanul, hatoda $(17,4 \%)$ pedig gazdasági képzésben vesz részt. Gazdasági-társadalmi hátterükre az jellemző, hogy kétötödük az átlagosnál jobbnak ítéli családja társadalmi státuszát, ehhez közel hasonló arányuk szerint családjuk helyzete átlagos, míg nyolcaduk nyilatkozott úgy, hogy az átlagosnál rosszabb helyet foglalnak el a társadalomban. Szubjektív jóllétüket tekintve, túlnyomó többségük elégedett az életével (háromötödük az inkább, vagy nagyon elégedett életével opciót jelölte be egy öt fokú skálán) és boldognak tekinti magát (hétből öt válaszadó ötnél magasabb pontszámra értékelte boldogságérzetét egy hét fokú skálán). A kulturális és társadalmi erőforrások szerint jellemezve a mintát legjellemzőbb a két idegen nyelv ismerete (minden második válaszadó két, harmaduk legfeljebb egy, míg hatoduk három vagy több idegen nyelven beszél), a barátok átlagos száma ${ }^{9} 9$, többségük (több mint kétharmaduk) gyakran beszélget közéleti kérdésekről az ismerőseivel, barátaival és az általánosított bizalmi szintjük magas (51\%-uk véleménye szerint általában vagy majdnem mindig meg lehet bízni az emberekben).

\footnotetext{
${ }^{7}$ Valamennyi nagy magyarországi felsőoktatási intézményt felkerestük, de a hallgatók online kérdőíves eléréséhez engedélyt és segítséget nem kaptunk minden egyetemen. Ezúton köszönjük a Budapesti Corvinus Egyetem, a Budapesti Múszaki és Gazdaságtudományi Egyetem, a Budapesti Gazdasági Egyetem, a Budapesti Metropolitan Egyetem, a Debreceni Egyetem, a Dunaújvárosi Egyetem, az Eötvös Loránd Tudományegyetem, az Eszterházy Károly Egyetem, a Károli Gáspár Református Egyetem, az Óbudai Egyetem, a Pannon Egyetem, a Pécsi Tudományegyetem és a Szegedi Tudományegyetem vezetőségének együttműködését, és diákjainak, hogy vállalták a vizsgálatban való részvételt.

${ }^{8}$ A célpopulációba a hazai nagy egyetemeken műszaki, természettudományi, társadalomtudományi és gazdasági képzési területen nappali munkarendben tanulók tartoznak. A kutatásba bevont szakok alapján értelmezett célpopuláció 26291 főből áll (Oktatási Hivatal, 2017/18-as tanév). Teljeskörű megkereséssel számolva megállapítható, hogy kb. minden nyolcvanadik hallgató, azaz az összes hallgató 1,3\%-a töltötte ki a kérdőívet. Az adatok nem reprezentatívak, a feltárt összefüggések a mintára érvényesek.

${ }^{9}$ A kiugróan magas értékek torzító hatásának kiszűrése érdekében azon válaszadók esetében, akik úgy nyilatkoztak, hogy több mint 25 barátjuk van, 25 baráttal számoltunk.
} 


\section{TEMATIKUS TANULMÁNYOK - Emberierőforrás-menedzsment napjainkban}

\section{Változók és kutatási design}

Kutatásunkban a különböző vezetési stílusokkal való azonosulás mérésére a nemzetközi kutatási gyakorlatban elterjedt Multifactor Leadership Questionnaire (Avolio - Bass 1990, Avolio - Bass - Jung 1996) öt változata közül egy rövidebb, önértékelő verziót használtunk. A felsorolt állításokkal való egyetértést - melyek 36 elképzelt szituációban mérik a fiatalok vezetőként való viselkedését, irányítói, döntéshozatali magatartását - egy ötfokozatú Likert-skála segítségével fejezhették ki a válaszadók. ${ }^{10}$

A kérdőív emellett információkat tartalmaz a válaszadó egyetemisták vezetői és vállalkozói hajlandóságáról, vállalkozói terveiről, továbbá vizsgálta a vállalkozásalapítással és annak finanszírozásával kapcsolatos elképzeléseiket. A diákok attitűdjeinek részletes megismerésére nem volt lehetőségünk, de a külföldi tapasztalatok, a bizalmi kapcsolatok, a közéleti tájékozottság tekintetében rendelkezésre állnak adatok.

A fiatalok által preferált vezetői típusok feltérképezéséhez először a kérdőívben alkalmazott 36 tételes skála alapján főkomponens-elemzéssel vizsgáltuk, hogy milyen látens struktúra húzódik meg az állítások mögött. A faktorelemzés négy jól elkülönülő faktort azonosított. Alapvető kérdésünk az volt, hogy a preferált vezetői stílusjegyek milyen összefüggésben állnak a válaszadó személyes vezetői és vállalkozói hajlandóságával, ha mindezeket a szociodemográfiai adottságokra, a kulturális és társadalmi erőforrásokra kontrolláljuk. A kutatás felépítését az alábbi ábra foglalja össze.

\section{2. ábra. Kutatási design}

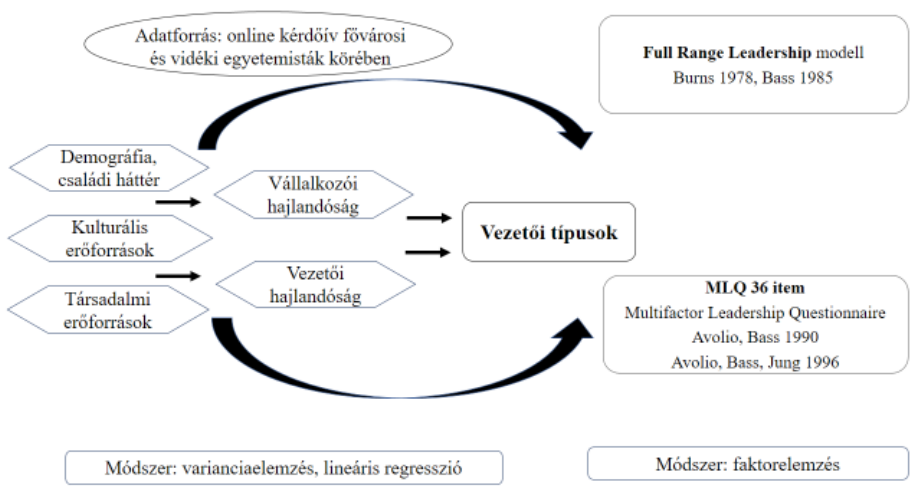

Forrás: Saját szerkesztés

${ }^{10}$ A kérdőívben szereplő kérdés: Képzeld el, hogy vezető lettél és vezetőként irányítasz embereket, hozol döntéseket! Kérjük, jelöld meg, milyen gyakran lennének jellemzőek vezetési stílusodra az alábbiak, úgy, hogy minden állítás mellé bejelölöd a megfelelő számot a 0 és 4 közötti skálán $(0=$ soha és 4 = mindig). Megjegyezzük, hogy az értelmezések megkönnyítése érdekében ezt a kódolást elemzésünk során 1-től 5-ig terjedő skálára transzformáltuk. 


\section{TEMATIKUS TANULMÁNYOK - Emberierőforrás-menedzsment napjainkban}

\section{A kutatás eredményei}

\section{VEZETÉSI STÍLUSOK ÉS PREFERÁLÁSUK AZ ELTÉRŐ SZOCIODEMOGRÁFIAI, KULTURÁLIS HÁTTERŰ CSOPORTOKBAN}

Első kutatási kérdésünk arra irányult, hogy milyen vezetési stílusokkal azonosulnak az egyetemi hallgatók. A vezetési stílusokkal való azonosulás mérésére a 36 állításon végzett faktorelemzés (főkomponens módszer, varimax rotáció) négy faktort azonosított (1. táblázat). A Kaiser-Mayer-Olkin-féle kritérium értéke: 0,84 ( $\chi^{2}: 3158,05$; Sig: 0,000). A faktorok az eredeti, mért változók információtömegéből 47\%-nyit őriznek meg. ${ }^{11}$

1. táblázat. A vezetési stílusokkal való azonosulást mérő változók faktorelemzésének eredménye (faktorsúlyok)

\begin{tabular}{|l|c|c|c|c|}
\hline \multirow{2}{*}{\multicolumn{1}{|c|}{ Rotált faktor mátrix* }} & \multicolumn{4}{c|}{ Komponens } \\
\cline { 2 - 5 } & $\mathbf{1 . \text { faktor }}$ & 2. faktor & 3. faktor & 4. faktor \\
\hline Meggyőző jövőkép & 0,698 & 0,191 & $-0,039$ & $-0,128$ \\
\hline Céllal való azonosulás & 0,657 & 0,174 & 0,107 & $-0,054$ \\
\hline Hatalom és bizalom & 0,616 & $-0,157$ & 0,250 & $-0,231$ \\
\hline Optimista jövőkép & 0,585 & 0,204 & $-0,205$ & $-0,036$ \\
\hline Munkára lelkesítés & 0,584 & 0,228 & 0,009 & $-0,196$ \\
\hline Célok iránti bizalom & 0,578 & 0,388 & $-0,060$ & $-0,011$ \\
\hline Tiszteletkeltés & 0,561 & 0,134 & 0,173 & $-0,190$ \\
\hline Büszkeség felkeltése & 0,534 & 0,017 & 0,098 & $-0,064$ \\
\hline Kollektív küldetéstudat & 0,525 & 0,228 & $-0,017$ & 0,111 \\
\hline Célelérés következménye & 0,365 & 0,361 & 0,181 & $-0,228$ \\
\hline Felelősség tisztázása & 0,334 & $-0,029$ & 0,218 & $-0,222$ \\
\hline Értékek kommunikálása & 0,322 & 0,254 & 0,081 & 0,002 \\
\hline Elégedettség kifejezése & 0,278 & 0,265 & 0,001 & $-0,205$ \\
\hline
\end{tabular}

${ }^{11}$ Mivel a háromfaktoros elméleti modell illeszkedési mutatói nem bizonyultak megfelelőnek, ezért bizonyos tételek eltávolítása helyett alternatív modelleket teszteltünk. Arra törekedtünk, hogy az MLQ lehető legoptimálisabb struktúráját alakítsuk ki, így a különböző faktorstruktúrájú modellek eredményei alapján a négyfaktoros struktúra mellett döntöttünk. A négyes faktorstruktúra esetében kisebb az információveszteség, az eredeti változók heterogenitásának magasabb százalékát őrzi meg a négy, mint három faktor (33\%). 


\section{TEMATIKUS TANULMÁNYOK - Emberierőforrás-menedzsment napjainkban}

Az 1. táblázat folytatása

\begin{tabular}{|l|c|c|c|c|}
\hline \multirow{2}{*}{\multicolumn{1}{|c|}{ Rotált faktor mátrix* }} & \multicolumn{4}{c|}{ Komponens } \\
\cline { 2 - 5 } & $\mathbf{1 . f a k t o r}$ & 2. faktor & 3. faktor & 4. faktor \\
\hline Többféle perspektíva elvárása & $-0,003$ & 0,659 & 0,074 & $-0,021$ \\
\hline Erősségek fejlesztése & 0,306 & 0,569 & $-0,019$ & $-0,240$ \\
\hline Új utak keresése & 0,219 & 0,475 & 0,081 & $-0,043$ \\
\hline Etikai következmények & 0,312 & 0,472 & $-0,058$ & 0,069 \\
\hline Kritikai felvetések vizsgálata & 0,011 & 0,450 & 0,097 & $-0,046$ \\
\hline Csoportérdek követése & 0,279 & 0,431 & 0,000 & $-0,033$ \\
\hline Többféle perspektíva alkalmazása & 0,225 & 0,418 & $-0,072$ & $-0,136$ \\
\hline Mások segítése & 0,122 & 0,396 & $-0,110$ & $-0,146$ \\
\hline Egyéni kezelésmód & 0,123 & 0,394 & 0,156 & $-0,128$ \\
\hline Tanítás és mentorálás & 0,278 & 0,389 & 0,181 & $-0,228$ \\
\hline Panaszokra koncentrálás & $-0,092$ & 0,050 & 0,667 & 0,199 \\
\hline Hibák számontartása & 0,166 & $-0,062$ & 0,664 & $-0,022$ \\
\hline Elő́rásoknak való megfelelés & 0,174 & 0,140 & 0,607 & $-0,106$ \\
\hline Szabálytalanságokra fókuszálás & 0,044 & $-0,029$ & 0,560 & 0,227 \\
\hline Beavatkozás elkerülése & $-0,024$ & 0,115 & 0,302 & 0,178 \\
\hline Kivárás & $-0,057$ & $-0,235$ & 0,032 & 0,663 \\
\hline Cselekvés csak súlyos problémák esetén & $-0,041$ & $-0,052$ & 0,140 & 0,653 \\
\hline Kívülmaradás & $-0,140$ & $-0,091$ & 0,099 & 0,642 \\
\hline Döntések elkerülése & $-0,172$ & $-0,089$ & 0,000 & 0,630 \\
\hline Válaszok késleltetése & $-0,008$ & $-0,213$ & $-0,077$ & 0,645 \\
\hline Jelenlét hiánya & $-0,174$ & $-0,226$ & 0,101 & 0,540 \\
\hline Közbelépés halogatása & $-0,031$ & 0,055 & 0,074 & 0,529 \\
\hline
\end{tabular}

Extrakciós módszer: Főkomponens-elemzés. Forgatási módszer: Varimax Kaiser normalizációval

*Megjegyzés: Forgatás 7 iteráció után.

Forrás: Saját szerkesztés

Az első faktorhoz a lelkesítő motiválás, az erőfeszítésekre és produktivitásra ösztönzés, a kollektív küldetéstudat, a közös teljesítendő célok elérését hangsúlyozó és az érdekeket jól képviselő változók tartoznak. Mivel ez a faktor a szakirodalomban számontartott transzformatív vezetési modell stílusjegyeit hordozza, transzforma- 


\section{TEMATIKUS TANULMÁNYOK - Emberierőforrás-menedzsment napjainkban}

tívnak, vagy bővebben az itemek jellegéhez igazodva „transzformatív-inspiratívnak” nevezzük.

A második faktorhoz tartozó változók között az egyéni képességek felismerése és azok fejlesztése, a feladatok személyre szabása, az egyéni mentorálás, gondoskodás és figyelem jelenik meg hangsúlyosan, továbbá az egyéni igyekezet és a kitűzött feladatok teljesítésének jutalmazása. Ez a faktor a szakirodalom tranzaktív típusának egy sajátos metszete, ahol a beosztottak támogatásán, az egyedi emberre figyelésen és a többféle perspektíva mérlegelésén van a hangsúly. A stílusjegyek sajátosságaiból kiindulva ezt a típust szupportívnak, vagy bővebben „szupportív-prudensnek” neveztük el. Az 1. táblázatban látható, hogy a transzformatív és a szupportív faktorok közt három item esetében, melyek a bizalom és a transzparencia elemeit jelenítik meg, átfedés van, tehát ezek a tulajdonságok mindkét vezetési stílusban érvényesülnek.

A harmadik faktorba tömörülő változók alapján kirajzolódik egy „defenzív” típus, melynek stílusjegyei között hangsúlyosan jelenik meg a hibák, kudarcok számontartása és az előírásoknak, szabályoknak való megfelelés. Ez a faktor részben ugyancsak átfed a szakirodalom által leírt tranzaktív típussal, de nem tartalmazza annak pozitív, csak negatív korlátozó elemeit. ${ }^{12}$

Végül a negyedik faktor egyértelműen a szakirodalom „laissez-faire” modelltípusának elemeit sűríti: a vezető minimális érdeklődéssel szemléli a munkahelyi eseményeket, igyekszik távolítani a döntéshozatalt, illetve már csak akkor avatkozik be, amikor az elkerülhetetlen.

A következőkben azt vizsgáltuk, hogy a válaszadó egyetemistákra mennyire jellemző a négy vezetési stílusfaktor külön-külön. A faktorok demográfiai, társadalmi, kulturális hátterét egyutas varianciaelemzés segítségével tártuk fel $(\mathrm{p}<0,1$ szignifikanciaszintet elfogadva). A részletes eredményeket, a faktorok átlagértékeit és szórását a vizsgált dimenziók szerint a Melléklet M1. táblázat tartalmazza. Az eredmények alapján a következő megállapításokat fogalmazhatjuk meg.

\footnotetext{
${ }^{12}$ Fontosnak tartjuk megemlíteni, hogy a defenzív, hibákra koncentráló stílus mind a három-, mind a négy-, mind az ötfaktoros modellekben is egyértelműen elkülönül, tehát mindenképpen célszerű a tranzaktív stílustól külön típusként megjeleníteni - eltérően a FRL modelltől.
} 


\section{TEMATIKUS TANULMÁNYOK - Emberierőforrás-menedzsment napjainkban}

3. ábra: A háttérváltozók és a vezetői típusok közötti összefüggések

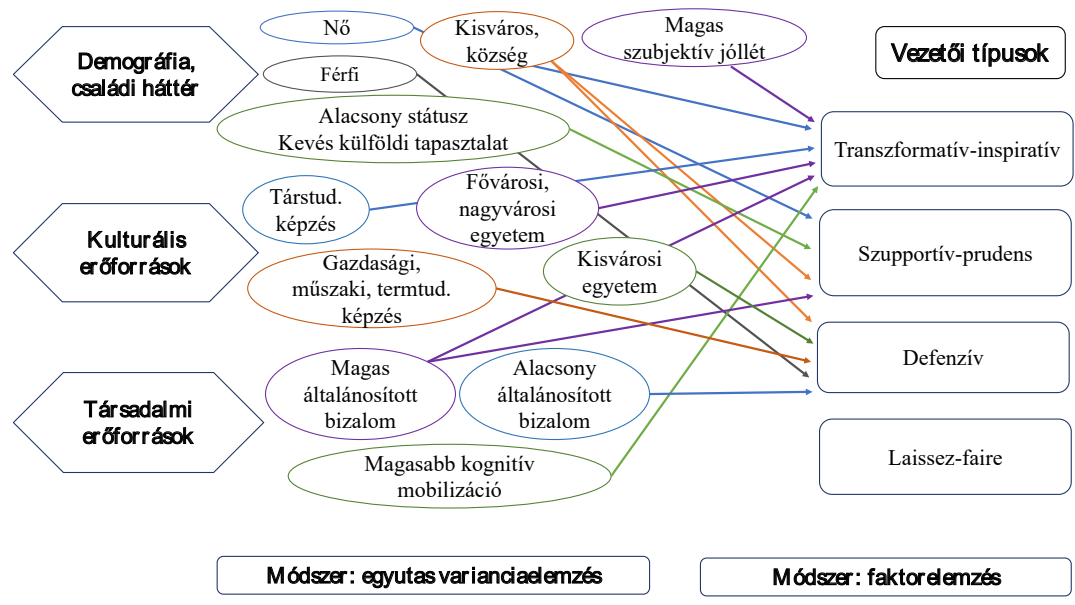

Forrás: Saját szerkesztés

Nemek között három faktor esetében mutatkozik szignifikáns eltérés: a lányok körében jellemzőbb a szupportív és a transzformatív, a fiúk körében pedig a defenzív stílussal azonosulás. A születési hely településtípusát tekintve elmondható, hogy a kisvárosi és községi születésűek között a többiekhez képest jellemzőbb mind a szupportív, mind a defenzív vezetési stílus, míg ezek a fővárosi születésűek körében lényegesen kevésbé. A család társadalmi és anyagi hátterének mérésére alkalmazott szubjektív mutatók tekintetében csupán egyetlen faktor esetében mutatnak a csoportok szignifikáns eltérést, méghozzá az alacsonyabb társadalmi és anyagi státuszú családból származó diákokra - azokra, akik a családjuk társadalmi helyzetére az átlagosnál rosszabb pontszámokat adtak és akik az elmúlt öt évben az átlagnál kevesebbszer jártak külföldön - szignifikánsan jellemzőbb a szupportív vezetési stílus. A szubjektív jóllét esetében az rajzolódik ki, hogy a többiekhez viszonyítva az életükkel elégedettekre szignifikánsan jellemzőbb a transzformatív vezetési stílus preferálása. A társadalmi erőforrások különböző dimenzióit vizsgálva elmondható, hogy a kognitív mobilizáció magasabb szintje - vagyis a barátokkal, ismerősökkel közéleti, politikai kérdésekről folytatott gyakori beszélgetés - pozitív kapcsolatot mutat a transzformatív vezetési stílus elfogadásával (míg a többi faktor esetében nem figyelhető meg szignifikáns eltérés a csoportok között). A társadalmi erőforrások mérésére a kérdőívben alkalmazott további változó, az általánosított bizalom tekintetében az látható, hogy a magasabb fokú bizalom pozitív kapcsolatban áll mind a szupportív, mind a transzformatív vezetési stílus preferálásával, az alacsonyabb bizalmi szint pedig a defenzív vezetési stílusfaktor elfogadásával. További szignifikáns eltérések jelentkeznek a csoportátlagok között a felsőfokú tanulmányok jellege és a képzés hely- 


\section{TEMATIKUS TANULMÁNYOK - Emberierőforrás-menedzsment napjainkban}

színe esetén, olyan módon, hogy a többiekhez képest a társadalomtudományi területen tanulók között jellemzőbb a transzformatív stílusfaktor preferálása, a gazdaságtudományi és a műszaki, illetve természettudományi területeken tanulók között pedig a defenzív stílus. A tanulmányok helyszínét tekintve elmondható, hogy a fővárosban és vidéki nagyvárosokban (Szegeden, Debrecenben, Miskolcon, Pécsett) tanuló egyetemisták körében a transzformatív vezetési stílus preferáltabbnak mutatkozik, a kisebb vidéki egyetemeken tanulókra pedig szignifikánsan jellemzőbb a defenzív vezetési stílussal való azonosulás. Más háttérváltozók tekintetében nem mutatkoztak statisztikailag szignifikáns eltérések, ilyenek voltak a kulturális erőforrások mérésére alkalmazott idegennyelv-tudás, a szubjektív társadalmi mobilitás, a társas kapcsolatok, a pénzügyi-vállalkozási kurzuson való részvétel és a felsőfokú tanulmányok képzési szintje.

\section{VEZETÉSI STÍLUSOK, VEZETŐI ÉS VÁLLALKOZÓI HAJLANDÓSÁG}

Második kutatási kérdésünk a vezetési stílusok és a vezetői, vállalkozói aspirációk összefüggésére vonatkozott. A szakirodalom (Hofmeister et al. 2015) alapján azt feltételezzük, hogy a transzformatív és szupportív vezetési stílusok preferálása összefügg a vállalkozói hajlandósággal. A kérdés megválaszolásához többváltozós magyarázó modelleket vizsgáltunk. Hangsúlyozzuk, elemzésünk feltáró jellegű: elsősorban a különböző vezetési stílusokkal való azonosulás és a vezetői, vállalkozói hajlandóság kapcsolatára fókuszál.

Az elemzésben használt függő változók tehát - az előző fejezetben ismertetett különböző vezetési stílusjegyeket tömörítő faktorok, és mivel folytonos változók, ezért a legkisebb négyzetek módszerét (OLS) alkalmazó lineáris regressziós modellek segítségével történt az elemzés. ${ }^{13}$ A modellek kialakításakor a magyarázó változók között (1) a vezetői, és vállalkozói hajlandóság mutatói mellett (2) a demográfiai és a családi háttér változói, (3) a társadalmi erôforrások mutatói és (4) a kulturális erőforrások (a képzés jellemzői) szerepeltek.

(1) A VEzETŐI és a VÁLLALKOZÓI HAJLANDósÁG mérésére dichotóm változókat alkalmaztunk (1, ha szívesen lenne vezető és 0 , ha nem vagy attól függ; 1 , ha szívesen lenne vállalkozó és 0 , ha nem vagy attól függ). Az eredmények alapján a mintába került egyetemisták 47,2 \%-a szívesen lenne vezető és 47,8\%-a szívesen lenne vállalkozó. Bár az arányok hasonlóak és a két szerep közt nyilvánvaló kapcsolat van, a vezetői és a vállalkozói hajlandóság mégsem esik egybe. A vezetői hajlandóságot mutatóknak csak 57,6\%-a lenne egyszersmind vállalkozó is.

${ }^{13}$ Az OLS regresszió a függő és a független változók között lineáris kapcsolatot feltételez, és ezt az összefüggést a függő változó várható értékeire illesztett lineáris függvénnyel határozza meg (Mészáros 2011). 


\section{TEMATIKUS TANULMÁNYOK - Emberierőforrás-menedzsment napjainkban}

(2) A válaszadó NEME szerint a lányok 1-es, a fiúk 0-ás kódot kaptak. A család társadalmi hátterét a diákok önbesorolása alapján írtuk le (SZUBJEKTív TÁRSADALMI Pozícıó) és mérésére az eredeti folytonos változót alkalmaztuk: a kérdőívben arra kértük a válaszadókat, hogy egy 10 fokú skálán jelöljék meg, hol helyezkedik el családjuk a társadalmi létrán (melyen 1-essel a legalsó és 10-essel a legfelső társadalmi helyzetet jelöltük).

(3) A diákok társadalmi erőforrásokkal való ellátottságához kétféle módon közelítettünk: az általánosított bizalom szintje és a kognitív mobilizációs kapacitások (Inglehart 1970) felől, és mindkettőt dichotóm változóként léptettük a modellekbe. Az ÁLTALÁNOSíTOTT BIZALOM változója azt méri, hogy mindig vagy általában meg lehet-e bízni az emberekben (a mintába került diákok 50,7\%-ának magas az általánosított bizalmi szintje, azaz szerintük majdnem mindig vagy általában meg lehet-e bízni az emberekben), a KoGNiTív MOBILIzÁcıó méréséhez pedig a barátokkal, ismerősökkel folytatott politikai tárgyú beszélgetések gyakoriságával közelítettünk (a mintában szereplő diákok 70,4\%-a gyakran szokott a barátaival, ismerőseivel közéleti kérdéseket megvitatni).

(4) A képzés szakterületének mérésére az elemzésben három dichotóm változót alkalmaztunk: GAZDASÁGTUDOMÁNY, TÁRSADALOMTUDOMÁNY, MÜSZAKI ÉS TERMÉSZETTUDOMÁNY. ${ }^{14}$ A mintában szereplők több mint hatoda $(17,4 \%$-a) gazdaságtudományi, majdnem fele (48,6\%-a) társadalomtudományi és harmada (33,9\%-a) müszaki, illetve természettudományi területen tanul. Végül a modellekbe bevontuk az egyetem elhelyezkedését mérő kétértékű változót KÉPZÉSI HELY néven, mely azt mutatja, hogy a diák nagyvárosban tanul-e (a mintába került diákok háromötöde a fővárosban vagy más vidéki nagyvárosban - Szegeden, Debrecenben, Miskolcon, Pécsett - és kétötöde kisebb vidéki városban tanul).

Megemlítjük, hogy több magyarázó változó nem került be a modellekbe a szignifikáns hatás hiánya miatt. Nincs fontos szerepe a vizsgált vezetési stílusok preferálásának magyarázatában a születési hely településtípusának, a szubjektív anyagi helyzetnek, jóléti mutatóknak és a kulturális erőforrások változóinak (beszélt idegen nyelvek száma, külföldi tapasztalat).

A regressziós elemzés során először külön modellekben vizsgáltuk a vezetői hajlandóság [(1) (4) (7) (10) modellspecifikáció] és a vállalkozói hajlandóság hatását [(2) (5) (8) (11) modellspecifikáció], majd olyan modelleket építettünk, melyek mindkét aspirációs változót tartalmazzák [(3) (6) (9) (12) modellspecifikáció].

${ }^{14}$ Mivel ebben az esetben a háromkategóriás nominális mérési szintű KÉPZÉSI SZAKTERÜLET-változóból három dummy változót építettünk a regressziós modellekbe, a függvényszerű multikollinearitás miatt a legnagyobb szórású független változót a regresszióelemzés kihagyja a modellből: esetünkben a társadalomtudományi képzési terület változója nem lépett a modellekbe. 


\section{TEMATIKUS TANULMÁNYOK - Emberierőforrás-menedzsment napjainkban}

A becslési eredményeket a 2-3. táblázatokban foglaltuk össze. ${ }^{15}$ A kontrollváltozókat mindegyik modell tartalmazza.

2. táblázat. A transzformatív-inspiratív és a szupportív-prudens vezetési stílusok elfogadásának összefüggése a vezetői és vállalkozói hajlandósággal - a lineáris regressziós modellek eredményei (standardizált béta-együtthatók), 2018, N = 335

\begin{tabular}{|l|c|c|c|c|c|c|}
\hline \multirow{2}{*}{} & \multicolumn{2}{|c|}{ Transzformatív-inspiratív } & \multicolumn{3}{c|}{ Szupportív-prudens } \\
\cline { 2 - 7 } & $\mathbf{( 1 )}$ & $\mathbf{( 2 )}$ & $\mathbf{( 3 )}$ & $\mathbf{( 4 )}$ & $\mathbf{( 5 )}$ & $\mathbf{( 6 )}$ \\
\hline VEZETŐI HAJLANDÓSÁG & $0,323^{* * *}$ & & $0,312^{* * *}$ & $-0,015$ & & $-0,032$ \\
\hline $\begin{array}{l}\text { VÁLLALKOZÓI } \\
\text { HAJLANDÓSÁG }\end{array}$ & & $0,115^{* *}$ & 0,057 & & 0,086 & $0,092^{*}$ \\
\hline NEME & $0,112^{* *}$ & 0,081 & $0,119^{* *}$ & $0,136^{* *}$ & $0,152^{* *}$ & $0,0148^{* *}$ \\
\hline $\begin{array}{l}\text { szubjektív társadalmi } \\
\text { pozíció }\end{array}$ & 0,018 & 0,039 & 0,017 & $-0,175^{* * *}$ & $-0,178^{* * *}$ & $-0,176^{* * *}$ \\
\hline általánosított bizalom & $0,116^{* *}$ & $0,159^{* * *}$ & $0,121^{* *}$ & $0,126^{* *}$ & $0,131^{* *}$ & $0,134^{* *}$ \\
\hline kognitív mobilizáció & $0,132^{* * *}$ & $0,154^{* * *}$ & $0,131^{* * *}$ & 0,012 & 0,008 & 0,011 \\
\hline gazdaságtudomány & $-0,030$ & $-0,045$ & $-0,036$ & 0,052 & 0,044 & 0,043 \\
\hline $\begin{array}{l}\text { műszaki és természet- } \\
\text { tudomány }\end{array}$ & $-0,102$ & $-0,144^{* *}$ & $-0,105$ & 0,005 & 0,005 & 0,001 \\
\hline képzési hely & 0,062 & $-0,006$ & 0,054 & $-0,037$ & $-0,043$ & $-0,049$ \\
\hline Sig & 0,000 & 0,000 & 0,000 & 0,008 & 0,003 & 0,005 \\
\hline Korrigált R & 0,16 & 0,08 & 0,16 & 0,06 & 0,05 & 0,07 \\
\hline
\end{tabular}

Magyarázat: ${ }^{* * *} p<0,01 ;{ }^{* *} p<0,05 ;{ }^{*} p<0,1$

Referenciacsoport: nem lenne szívesen vezető; nem lenne szívesen vállalkozó; fiú; az ember általában vagy szinte soha nem lehet elég óvatos másokkal szemben; soha vagy csak ritkán beszélget barátaival közéleti kérdésekről; társadalomtudományi képzési terület; kisebb vidéki városban folytatott egyetemi tanulmányok.

Forrás: Saját szerkesztés

\footnotetext{
${ }^{15}$ A lineáris regressziószámítás feltételeinek teljesülését mindegyik modell esetében ellenőriztük. A pontdiagram ábrákról leolvasható, hogy a standardizált reziduumok valamennyi modellben korrelálatlanok és normális eloszlásúak, továbbá a Kolmogorov-Smirnov-próba szignifikanciaszintje is megerősítette a hibatagok normális eloszlását (K-S szignifikanciaszintje 0,227 és 0,548 közötti, azaz minden esetben nagyobb, mint 0,05); valamint a modellek futtatásánál lekértük a VIF értékeket is, melyek minden esetben a multikollinearitás hiányát jelezték (VIF $<2$ és tolerancia $>0,5$ ).
} 


\section{TEMATIKUS TANULMÁNYOK - Emberierőforrás-menedzsment napjainkban}

3. táblázat. A defenzív és a laissez-faire vezetési stílusok elfogadásának összefüggése a vezetői és vállalkozói hajlandósággal - a lineáris regressziós modellek eredményei

(standardizált béta-együtthatók), 2018, N = 335

\begin{tabular}{|l|c|c|c|c|c|c|}
\hline & \multicolumn{3}{|c|}{ Defenzív } & \multicolumn{3}{c|}{ Laissez-faire } \\
\hline & $\mathbf{( 7 )}$ & $\mathbf{( 8 )}$ & $\mathbf{( 9 )}$ & $\mathbf{( 1 0 )}$ & $\mathbf{( 1 1 )}$ & $\mathbf{( 1 2 )}$ \\
\hline VEZETŐI HAJLANDÓSÁG & $-0,109^{* *}$ & & $-0,115^{* *}$ & $-0,205^{* * *}$ & & $-0,192^{* * *}$ \\
\hline $\begin{array}{l}\text { VÁLLALKOZÓI } \\
\text { HAJLANDÓSÁG }\end{array}$ & & $-0,060$ & $-0,080$ & & $-0,107^{*}$ & $-0,071$ \\
\hline NEME & $-0,084$ & $-0,107^{*}$ & $-0,094^{*}$ & $-0,110^{*}$ & $-0,096$ & $-0,120^{* *}$ \\
\hline $\begin{array}{l}\text { szubjektív társadalmi } \\
\text { pozíció }\end{array}$ & 0,007 & 0,015 & 0,008 & 0,025 & 0,013 & 0,026 \\
\hline általánosított bizalom & $-0,167^{* * *}$ & $-0,160^{* * *}$ & $-0,164^{* * *}$ & 0,052 & 0,025 & 0,045 \\
\hline kognitív mobilizáció & $-0,026$ & $-0,017$ & $-0,024$ & 0,082 & 0,068 & 0,083 \\
\hline gazdaságtudomány & 0,100 & $0,105^{*}$ & $0,108^{*}$ & 0,073 & 0,086 & 0,080 \\
\hline $\begin{array}{l}\text { múszaki és természet- } \\
\text { tudomány }\end{array}$ & 0,031 & 0,021 & 0,034 & $-0,002$ & 0,025 & 0,001 \\
\hline képzési hely & $-0,088$ & $-0,098$ & $-0,077$ & 0,079 & $0,127^{*}$ & 0,089 \\
\hline Sig & 0,001 & 0,002 & 0,001 & 0,010 & 0,089 & 0,010 \\
\hline Korrigált R ${ }^{2}$ & 0,05 & 0,05 & 0,08 & 0,03 & 0,03 & 0,04 \\
\hline
\end{tabular}

Magyarázat:*** $p<0,01 ;{ }^{* *} p<0,05 ;{ }^{*} p<0,1$

Referenciacsoport: nem lenne szívesen vezető; nem lenne szívesen vállalkozó; fiú; az ember általában vagy szinte soha nem lehet elég óvatos másokkal szemben; soha vagy csak ritkán beszélget barátaival közéleti kérdésekről; társadalomtudományi képzési terület; kisebb vidéki városban folytatott egyetemi tanulmányok.

Forrás: Saját szerkesztés

A modellek mindegyike szignifikáns, de magyarázó erejük nagyon eltérő: a bevont változók a függő változó varianciájának legnagyobb hányadát a transzformatív-inspiratív vezetési stílus preferálása esetében magyarázzák.

Akár a teljes modelleket, akár csak a vezetői aspirációkat mérő változót tartalmazó modelleket nézzük, a vizsgált négy faktor közül három mutat szignifikáns összefüggést a vezetői hajlandósággal: minden más bevont változó hatását kiszürve a vEZETőI HAJLANDóSÁG pozitívan befolyásolja a transzformatív vezetési stílus preferálását és negatívan a defenzív, valamint a laissez-faire vezetés elfogadását.

A váLLALKOzóI HAJLANDósÁG hatásával kapcsolatban az látható, hogy azok az egyetemisták, akik szívesen lennének vállalkozók, inkább a transzformatív és a szupportív vezetési stílussal azonosulnak. A vezetői és vállalkozó aspirációk együttes hatását vizsgáló teljes modellben a vállalkozói hajlandóság a tranzaktív típusnak 


\section{TEMATIKUS TANULMÁNYOK - Emberierőforrás-menedzsment napjainkban}

azzal a - pozitív elemeket tartalmazó - komponensével mutat összefüggést, amit szupportív-prudens vezetői stílusnak neveztünk. Az önálló hatást tesztelő modellekben a vállalkozói hajlandóság pozitív kapcsolatban áll a transzformatív és negatív kapcsolatban a laissez-faire stílussal.

A válaszadó NEME mind a négy faktor esetében jelentősnek bizonyul: a lányok a transzformatív-inspiratív és a szupportív-prudens vezetési stílussal, a fiúk viszont inkább a defenzív és passzív vezetéssel azonosulnak. A válaszadók társadalmi hátterének mérésére alkalmazott SzUBJEKTÍv TÁRSADALMI POzíció hatását vizsgálva egyetlen stílusfaktor esetében kaptunk szignifikáns összefüggést: az alacsonyabb társadalmi helyzetűek nagyobb valószínűséggel preferálják a szupportív-prudens vezetési stílust.

A társadalmi erőforrások különböző vezetési stílusok elfogadására gyakorolt hatását több dimenzióban vizsgáltuk. Az ÁLTALÁNOSÍTOTT BIZALOM változó azt mutatja, hogy a magas bizalmi szint pozitívan befolyásolja mind a transzformatív-inspiratív, mind a szupportív-prudens vezetési stílus elfogadását, ugyanakkor negatív kapcsolatban áll a defenzív vezetéssel. A társadalmi tőke mérésére alkalmazott másik indikátor, a KOGNITÍv MOBILIZÁció hatásával kapcsolatban azt látjuk, hogy akik a barátaikkal, ismerőseikkel gyakran beszélgetnek közéleti kérdésekről, inkább preferálják a transzformatív-inspiratív vezetést a politikai kérdésekről barátaikkal soha vagy csak ritkán beszélgető társaikhoz képest.

Végül a képzési jellemzők hatását tekintve, a GAZDASÁGTUDOMÁNYI KÉPZÉSI TERÜLET pozitívan befolyásolja a defenzív vezetési stílus elfogadását, míg az egyetem elhelyezkedése a teljes modellekben nem szignifikáns hatású (a vállalkozói aspirációkat tartalmazó modellek közül egyetlen esetben van szignifikáns kapcsolat: a fóvárosi és nagyvárosi egyetemek diákjai inkább a laissez-faire vezetéssel azonosulnak a kisebb vidéki városokban tanulókhoz képest, ám ha a modellben a vezetői hajlandóság változója is szerepel, nem szignifikáns együtthatója).

\section{Összegzés, következtetések}

Tanulmányunkban egy 2018-ban készült online kérdőíves kutatás adatbázisának felhasználásával azt vizsgáltuk, hogy milyen vezetési stílussal azonosulnak a magyar egyetemista fiatalok, majd feltártuk az azonosított vezetési stílusfaktorok sajátosságait demográfiai, kulturális és társadalmi különbségek mentén. A kétváltozós elemzések után többváltozós regresszióval elemeztük központi témánk, a vezetési stílusok, valamint a vezetői és a vállalkozói hajlandóság összefüggését.

A Full Range Leadership modellt tehát nem vezetők vagy beosztottak, hanem egyetemi hallgatók körében teszteltük. Tanulmányunk további hozzáadott értékét a potenciális vezetési stílusok és a vállalkozói hajlandóság összefüggésének vizsgálata adja. Kutatásunk során abból a feltételezésből indultunk ki, hogy a hatékony - az 


\section{TEMATIKUS TANULMÁNYOK - Emberierőforrás-menedzsment napjainkban}

eredeti Full Range Leadership modell szóhasználatával élve: elsősorban transzformatív, másodsorban tranzaktív - vezetési stílusok elfogadása és a vállalkozói hajlandóság összefügg egymással.

Eredményeink a vizsgált mintára érvényesek, s arra alkalmasak, hogy hipotéziseket fogalmazzunk meg. Ezek alapján feltehető, hogy négy jól elhatárolható vezetési stílusfaktor rajzolódik ki az egyetemisták körében. Az első, a transzformatív-inspiratív faktor egy lelkesítő, produktivitásra motiváló, integritáson alapuló vezetési kultúrát testesít meg. A második faktor olyan vezetési eszközöket és szemléletet jelent, melyben a hangsúly a különböző perspektívák mérlegelésén, a vezetettek támogatásán és az egyes emberre figyelésen van, ezért szupportív-prudens faktornak neveztük el. A harmadik egy defenzív vezetői típust ír le és olyan elemeket tartalmaz, melyekben a hibák, kudarcok számontartásán, valamint a szabályoknak való megfelelésen van a hangsúly. Végül a negyedik faktor a laissez-faire stílus egy passzív, a döntésektől és sürgető kérdésektől távolmaradó, a problémákba be nem avatkozó vezető típusát ragadja meg. Eredményeink azt jelzik, hogy a fiatalok neme, társadalmi háttere, társadalmi erőforrásokkal való ellátottsága és a felsőfokú képzés jellemzői szerint is találunk eltéréseket az egyes vezetési stílusok tekintetében. A transzformatív vezetési típus inkább a lányok és a társadalmi erőforrásokkal ellátott diákok (azaz a magas bizalmi szintű és barátaikkal közéleti kérdésekről gyakran beszélgetők) körében preferált. A szupportív vezetési stílussal való azonosulás szintén a lányokat és a magas bizalmi szinttel rendelkezőket jellemzi, de az elemi összefüggések szintjén preferáltabb az alacsonyabb társadalmi státuszú és kedvezőtlenebb anyagi helyzetű egyetemisták körében is. A defenzív vezetési stílus viszont a kisvárosi vagy községi születésű és alacsony bizalmi szinttel rendelkező, kisebb vidéki egyetemek gazdaságtudományi képzésein tanulók körében elfogadott.

Kutatásunk egyfajta feltáró jelleggel megmutatta a fiatalok által preferált vezetési stílusok, valamint a vállalkozói és vezetői aspirációk összefüggését. A tanulmány e fő kutatási kérdéseinek megválaszolásához többváltozós regresszió-elemzést végeztünk. Ennek során azt tapasztaltuk, hogy a transzformatív vezetési stílus külön-külön a vezetői és a vállalkozói hajlandósággal is összefügg, azonban ha együttes hatásukat vizsgáljuk, akkor a vezetői hajlandóság dominál és a vállalkozói hajlandóság inszignifikánssá válik. A vezetői hajlandóság negatív kapcsolatban áll a defenzív és a laissez-faire stílusokkal, a vállalkozói hajlandóság a laissez-faire stílussal. A vállalkozói hajlandóság önmagában összefügg a transzformatív stílusjegyekkel, ám a vezetői hajlandósággal közös modellbe vonva a szupportív stílussal mutat szignifikáns összefüggést. Feltehető ezek alapján tehát, hogy a leendő vezetők inkább a transzformatív, míg a potenciális vállalkozók a transzformatív és a szupportív vezetői stílusjegyeket preferálják. 


\section{TEMATIKUS TANULMÁNYOK - Emberierőforrás-menedzsment napjainkban}

\section{Irodalom}

Avolio, B. J. - Bass, B. M. (1990): Transformational leadership development: Manual for the Multifactor Leadership Questionnaire. Palo Alto, CA, Consulting Psychologist Press.

Avolio, B. J. - Bass, B. M. - Jung, D. (1996): Construct validation of the multifactor leadership questionnaire. MLQ-Form 5X,CLS Report 96-1.

Avolio, B. J. - Bass B. M. - Jung, D. I. (1999): Re-examining the components of transformational and transactional leadership using the Multifactor Leadership Questionnaire. Journal of Occupational and Organizational Psychology 72: 441462.

Bass, B. - Avolio, B. (2004): Multifactor Leadership Questionnaire Manual (Third Edition). Menlo Park, CA, Mind Garden, Inc.

Billig, M. (2015): Kurt Lewin's leadership studies and his legacy to social psychology: is there nothing as practical as a good theory? Journal for the Theory of Social Behaviour 45(4): 440-460.

Boda Zs. (2013): Politikai vezetés és kollektív cselekvés. Politikatudományi Szemle 22/2: 73-89.

Bryman, A. (1996): Leadership in Organizations. In: Clegg, S. R. (ed.): Handbook of Organization Studies. London, Sage, 276-292.

Burns, J. M. (1987): Leadership. New York, Harper and Row.

Chancy, S. (2017): The Multifactor Leadership Questionnaire (MLQ) as a determinant measure of leadership style. http://ascenditurno/blog/2017/04/16/mlqmeasure-leadership-style/. Letöltve: 2019. 05. 05.

Dzomonda, O. - Fatoki, O. - Oni, O. (2017): The Impact of Leadership Styles on the Entrepreneurial Orientation of Small and Medium Enterprises in South Africa. Journal of Economics and Behavioral Studies 9(2): 104-113.

Edwards, G. - Gill, R. (2012): Transformational Leadership across Hierarchical Levels in UK Manufacturing Organizations. Bristol Business School, University of the West of England, UK.

Etzioni, A. (1987): Entrepreneurship, adaptation and legitimation. A macrobehavioural perspective. Journal of Economic Behaviour and Organization, no. 8., 175-189.

Filep R. (2018): Vezetési stílus vizsgálata MLQ segítségével a szabolcs-szatmár-bereg megyei kisvállalkozások körében. International Journal of Engineering and Management Sciences, 3(4): 36-47.

Fitzsimmons, J. - Evans, D. J. (2005): Entrepreneurial attitudes and entrepreneurial intentions: A cross-cultural study of potential entrepreneurs in India, China, Thailand and Australia. Babson-Kauffmann Conference paper. Wellesley, MA. 


\section{TEMATIKUS TANULMÁNYOK - Emberierőforrás-menedzsment napjainkban}

Gregor, M. A. - O’Brien, K. M. (2016): Understanding Career Aspirations Among Young Women: Improving Instrumentation. Journal of Career Assessment, 24(3): 559-572.

Hofmeister Á. - Kopfer-Rácz K. - Sas D. (2015): A magyar kis- és közepes vállalkozások vezetőinek vállalkozói hajlandósága. Vezetéstudomány, 46(7): 41-51.

Imreh-Tóth M. - Bajmócy Z. - Imreh Sz. (2013): Vállalkozó hallgatók - Valóban reális jövőkép a vállalkozóvá válás? Vezetéstudomány, 44(7-8): 5-63.

Kelloway, E. K. - Barling, J. - Helleur, J. (2000): Enhancing transformational leadership: the roles of training and feedback. Leadership \& Organization Development Journal, 21(3): 145-149.

Koltai, J. P. - Szalka, É. (2013): A vállalkozói hajlandóság vizsgálata a női hallgatók körében Magyarországon. Vezetéstudomány, 44(7-8): 71-97.

Kuczi T. - Lengyel Gy. - Nagy B. - Vajda Á. (1991): Entrepreneurs and Potential Entrepreneurs. The Chances of Getting Independent. Society and Economy. No. 2., 134-150.

Kuczi T. - Lengyel Gy. (2001): The Spread of Entrepreneurship in Eastern Europe. In: Meusberger, P. - Jöns, H. (eds.): Transformations in Hungary. Essays in Economy and Society, Physica Verlag, Heidelberg, 157-172.

Mészáros J. (2011): Numerikus módszerek. Digitális Tankönyvtár, Miskolci Egyetem Földtudományi Kar, GEMAK 6841B.

Lengyel Gy. (szerk.) (1996): Vállalkozók és vállalkozói hajlandóság. Budapest, BKE.

Lengyel Gy. (2008): A vállalkozói hajlandóság hatása a vállalkozásra és a jólétre. A Magyar Háztartás Panel néhány tanulsága (1992-2007). In: Kolosi, T. - Tóth I. Gy. (szerk.): Társadalmi riport 2008. Budapest, Tárki, 429-450.

Lengyel, Gy. (2009): Entrepreneurial inclination, potential entrepreneurs and risk avoidance. In: Tóth I. Gy. (ed.): Tárki European Social Report 2009. Budapest, Tárki, 115-132.

Lengyel Gy. - Róna-Tas Á. (eds.) (1997): Entrepreneurship in Eastern Europe I. International Journal of Sociology, 27(3): 3-14.

Lowe, K. B. - Kroeck, G. K. - Sivasubramaniam, N. (1996): Effectiveness correlates of transformational and transactional leadership. A meta-analytic review of the MLQ literature. The Leadership Quarterly, 7(3): 385-425.

Likert, R. (1967): The human organization: its management and values. New York, NY, US, McGraw-Hill.

Öncer, A. Z. (2013): Ivestigation of the effects of transactional and transformational leadership on entrepreneurial orientation. International Journal of Business and Social Research, 3(4): 153-166. 


\section{TEMATIKUS TANULMÁNYOK - Emberierőforrás-menedzsment napjainkban}

Petheő A. I. (2013): Hallgatói vállalkozási tervek vizsgálata a GUESSS 2011-es felmérés alapján. Vezetéstudomány, 44(7-8): 64-70.

Radaev, V. (1997): Practicing and potential entrepreneurs in Russia. In: Lengyel Gy. Róna-Tas Á. (eds.): Entrepreneurship in Eastern Europe I. International Journal of Sociology, 27(3): 15-50.

Rauch, A. - Wiklund, J. - Lumpkin, G. T. - Frese, M. (2009): Entrepreneurial Orientation and Business Performance. An Assessment of Past Research and Suggestions for the Future. Entrepreneurship Theory and Practice, 33(3): 761-787.

Reisinger A. (2013): Családi vállalkozás folytatásának tervei a felsőoktatási hallgatók körében. Vezetéstudomány, 44(7-8): 41-50.

S. Gubik A. (2015): Understanding Career Aspirations of Hungarian Students. In: S. Gubik, A. - Wach, K. (eds.): Institutional Aspects of Entrepreneurship. Miskolc, University of Miskolc, 131-150.

S. Gubik A. - Farkas Sz. (2016): A karriermotívumok változásának hatásai a magyarországi hallgatók vállalkozásindítási elképzeléseinek alakulására. Vezetéstudomány, 47(3): 46-55.

S. Gubik A. - Farkas Sz. (2017): Entrepreneurship intentions and activity of students in Hungary. Global University Entrepreneurial Spirit Student's Survey 2016. National Report. W.p., Budapest Business School University of Applied Sciences University of Miskolc.

Shapero, A. - Sokol, L. (1982): The social Dimensions of Entrepreneurship. In: Kent, C. A. - Sexton, D. L. - Vesper, K. H. (eds.): The Encyclopedia of Entrepreneurship. New Jersey, Englewood Cliffs, Prentice Hall, 72-90.

Sheppard, L. D. (2018): Gender Differences in Leadership Aspirations and Job and Life Attribute Preferences among U.S. Undergraduate Students. Sex Roles 79(910): 565-577.

Stafford, M. (2010): The Full Range Leadership Model: A Brief Primer. Montgomery, Jeanne M. Holm Center.

Szerb L. - Lukovszki L. (2013): Magyar egyetemi hallgatók vállalkozási attitűdjei és az attitűdöket befolyásoló tényezők elemzése a GUESSS-felmérés adatai alapján Kik is akarnak ténylegesen vállalkozni? Vezetéstudomány, 4(7-8): 30-40.

Temesi M. (2014): A hallgatók vállalkozási hajlandóságának és az azt befolyásoló tényezők vizsgálata Magyarországon. E-conom, 3(1): 25-39.

Zaal, S. (2017): Differences in Leadership Styles Between Genders: Outcomes and Effectiveness on Team Succes. Ed.D. Dissertations. 
www. metszetek.unideb.hu

\section{TEMATIKUS TANULMÁNYOK - Emberierőforrás-menedzsment napjainkban}

\section{MELLÉKLET}

M1. táblázat: A faktorok szociodemográfiai, kulturális háttere

(egyutas varianciaelemzés, faktorok átlagértéke és szórása), 2018, N = 335

\begin{tabular}{|c|c|c|c|c|}
\hline & 1. faktor & 2. faktor & 3. faktor & 4. faktor \\
\hline & $\begin{array}{l}\text { Transzformatív- } \\
\text { inspiratív }\end{array}$ & $\begin{array}{l}\text { Szupportív- } \\
\text { prudens }\end{array}$ & Defenzív & Laissez-faire \\
\hline \multicolumn{5}{|c|}{ Neme } \\
\hline Fiú & $-0,152(1,09)$ & $-0,144(1,09)$ & $0,160(0,92)$ & $0,057(1,01)$ \\
\hline Lány & $0,101(0,92)$ & $0,087(0,92)$ & $-0,106(1,03)$ & $-0,043(0,99)$ \\
\hline Sig & 0,023 & 0,023 & 0,017 & NS \\
\hline \multicolumn{5}{|c|}{ Születési hely településtípusa } \\
\hline Főváros & $-0,020(1,01)$ & $-0,116(1,07)$ & $-0,106(1,04)$ & $-0,043(1,03)$ \\
\hline $\begin{array}{l}\text { Megyeszékhely, megyei jogú } \\
\text { város }\end{array}$ & $0,005(0,90)$ & $-0,002(1,04)$ & $-0,035(0,94)$ & $-0,043(0,98)$ \\
\hline Kisváros vagy község & $-0,012(1,11)$ & $0,114(0,84)$ & $0,154(1,03)$ & $0,103(0,99)$ \\
\hline Sig & NS & 0,078 & 0,068 & NS \\
\hline \multicolumn{5}{|c|}{ Szubjektív társadalmi pozíció } \\
\hline $\begin{array}{l}\text { Alacsony társadalmi státusz } \\
\text { (legfeljebb } 4 \text { pont) }\end{array}$ & $-0,071(1,19)$ & $0,222(0,95)$ & $0,215(0,90)$ & $-0,057(0,83)$ \\
\hline $\begin{array}{l}\text { Átlagos társadalmi státusz } \\
\text { (5-6 pont) }\end{array}$ & $-0,063(0,97)$ & $0,065(0,92)$ & $-0,008(0,96)$ & $0,001(1,03)$ \\
\hline $\begin{array}{l}\text { Magas társadalmi státusz } \\
\text { (legalább } 7 \text { pont) }\end{array}$ & $0,071(0,96)$ & $-0,114(1,06)$ & $0,050(1,05)$ & $0,014(1,01)$ \\
\hline Sig & NS & 0,091 & NS & NS \\
\hline \multicolumn{5}{|c|}{ Szubjektív anyagi helyzet } \\
\hline $\begin{array}{l}\text { Átlagos vagy átlag alatti } \\
\text { külföldi út }\end{array}$ & $-0,052(1,03)$ & $0,086(1,01)$ & $0,045(0,99)$ & $-0,035(1,00)$ \\
\hline Átlag feletti külföldi út & $0,120(0,92)$ & $-0,198(0,94)$ & $-0,104(1,03)$ & $0,082(0,98)$ \\
\hline Sig & NS & 0,016 & NS & NS \\
\hline \multicolumn{5}{|c|}{ Szubjektív jóllét } \\
\hline $\begin{array}{l}\text { Nagyon elégedetlen vagy in- } \\
\text { kább elégedetlen az életével }\end{array}$ & $-0,250(1,08)$ & $-0,040(1,09)$ & $0,049(0,93)$ & $-0,061(0,96)$ \\
\hline $\begin{array}{l}\text { Nagyon elégedett vagy in- } \\
\text { kább elégedett az életével }\end{array}$ & $0,149(0,91)$ & $0,024(0,93)$ & $-0,029(1,03)$ & $0,036(1,01)$ \\
\hline Sig & 0,000 & NS & NS & NS \\
\hline \multicolumn{5}{|c|}{ Kognitív mobilizáció } \\
\hline $\begin{array}{l}\text { Soha vagy csak ritkán beszél- } \\
\text { get ismerőseivel, barátaival } \\
\text { közéleti kérdésekről }\end{array}$ & $-0,267(1,21)$ & $-0,012(0,90)$ & $0,067(1,04)$ & $-0,110(0,96)$ \\
\hline $\begin{array}{l}\text { Gyakran beszélget ismerő- } \\
\text { seivel, barátaival közéleti } \\
\text { kérdésekről }\end{array}$ & $0,114(0,87)$ & $0,005(1,04)$ & $-0,021(0,97)$ & $0,052(1,01)$ \\
\hline Sig & 0,001 & NS & NS & NS \\
\hline
\end{tabular}


www: metsgretek:unideb:hu

\section{TEMATIKUS TANULMÁNYOK - Emberierőforrás-menedzsment napjainkban}

\begin{tabular}{|c|c|c|c|c|}
\hline \multicolumn{5}{|c|}{ Általánosított bizalom } \\
\hline $\begin{array}{l}\text { Soha vagy általában nem } \\
\text { lehet az ember elég óvatos } \\
\text { másokkal kapcsolatban }\end{array}$ & $-0,139(1,02)$ & $-0,112(1,03)$ & $0,170(0,94)$ & $-0,036(0,96)$ \\
\hline $\begin{array}{l}\text { Majdnem mindig vagy } \\
\text { általában meg lehet bízni az } \\
\text { emberekben }\end{array}$ & $0,134(0,95)$ & $0,109(0,95)$ & $-0,165(1,02)$ & $0,035(1,03)$ \\
\hline Sig & 0,012 & 0,042 & 0,002 & NS \\
\hline \multicolumn{5}{|c|}{ Felsôfokú tanulmányok képzési területe } \\
\hline Társadalomtudományi & $0,170(0,88)$ & $-0,052(0,99)$ & $-0,152(1,03)$ & $-0,012(0,99)$ \\
\hline $\begin{array}{l}\text { Múszaki, természettudo- } \\
\text { mányi }\end{array}$ & $-0,231(1,08)$ & $-0,006(1,05)$ & $0,094(1,03)$ & $-0,012(0,99)$ \\
\hline $\begin{array}{l}\text { Gazdaságtudományi és egyéb } \\
\text { képzési terület }\end{array}$ & $0,012(1,04)$ & $0,138(0,90)$ & $0,258(0,80)$ & $0,097(1,12)$ \\
\hline Sig & 0,004 & NS & 0,013 & NS \\
\hline \multicolumn{5}{|c|}{ Felsőfokú tanulmányok helye } \\
\hline $\begin{array}{l}\text { Nagyváros: Budapest, Sze- } \\
\text { ged, Debrecen, Miskolc, Pécs }\end{array}$ & $0,102(0,93)$ & $-0,032(1,03)$ & $-0,148(1,03)$ & $0,056(1,03)$ \\
\hline Egyéb képzési hely & $-0,135(1,06)$ & $0,042(0,95)$ & $0,196(0,91)$ & $-0,075(0,95)$ \\
\hline Sig & 0,031 & NS & 0,002 & NS \\
\hline
\end{tabular}

Forrás: Saját szerkesztés 